\title{
The Implementation of Strengthening Character Education Program through Scouts Extracurricular Activities in Islamic Senior High School
}

\author{
Abd Rahman ${ }^{1}$, Iim Wasliman ${ }^{2}$, Hanafiah $^{3}$, Yosal Iriantara ${ }^{4}$ \\ 1,2,3,4 Postgraduate Faculty, Universitas Islam Nusantara Bandung, Indonesia
}

\section{A R T I C L E IN F O}

\section{Article history:}

Received March 04, 2021

Revised March 05, 2021

Accepted October 24, 2021

Available online November 25, 2021

Kata Kunci :

Karakter Mulia, Ekstrakurikuler,

Pramuka

Keywords:

Noble Character, Extracurricular, Scouts

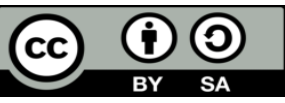

This is an open access article under the CC BY-SA license.

Copyright $(\mathcal{C} 2021$ by Author. Published by Universitas Pendidikan Ganesh

\begin{abstract}
A B S T R A K
Pendidikan akhlak mulia bagi siswa Sekolah Menengah Atas Agama Islam (MAN) sangat terkait dengan manajemen sekolah. Manajemen mengacu pada bagaimana pembentukan akhlak mulia direncanakan, dilaksanakan, dan dikendalikan dengan memberdayakan seluruh sumber daya sekolah dan tercermin dalam kegiatan pendidikan di sekolah. Meskipun demikian, implementasi pendidikan akhlak mulia bagi siswa MAN belum sepenuhnya disadari. Penelitian ini bertujuan untuk menganalisis program penguatan pendidikan akhlak mulia siswa MAN. Selain itu, juga mengkaji pelaksanaan dan dampak program penguatan pendidikan akhlak mulia siswa MAN. Penelitian ini menggunakan metode penelitian kualitatif dengan studi kasus. Metode yang digunakan untuk mengumpulkan data yaitu observasi, wawancara, dan dokumentasi. Insrumen yang digunakan untuk mengumpulkan data yaitu kuesioner. Teknik yang digunakan untuk menganalisis data yaitu analisis deskriptif kualitatif. Hasil penelitian yaitu pertama, program penguatan pendidikan akhlak mulia siswa MAN melalui kegiatan ekstrakurikuler pramuka terlaksana dengan baik. Kedua, pelaksanaan program pendidikan budi pekerti luhur siswa MAN melalui kegiatan ekstrakurikuler pramuka belum mencapai kualitas pelayanan yang baik karena sistem penilaian. Ketiga, dampak pelaksanaan penguatan akhlak mulia program pendidikan karakter siswa MAN melalui kegiatan ekstrakurikuler Pramuka telah mencapai tujuan; Namun, dampaknya hanya dapat dipantau ketika siswa berada di sekolah. Oleh karena itu, Madrasah Ibtidaiyah perlu menyusun SOP untuk membentuk akhlak mulia dengan mendukung kegiatan ekstrakurikuler.
\end{abstract}

\section{A B S T R A C T}

Noble moral education for Islamic Senior High School (MAN) is closely related to school management. Management refers to how the formation of noble character is planned, implemented, and controlled by empowering all school resources and educational activities in schools. However, the implementation of noble education for MAN students has not been fully realized. This study aims to analyze the noble character education program for MAN students. In addition, it also examines the implementation and impact of the program for strengthening noble character education for MAN students. This research uses qualitative research methods with case studies. The methods used to collect data are observation, interviews, and documentation. The instrument used to collect data is a questionnaire. The technique used to analyze the data is descriptive qualitative analysis. The results of the study were. First, the program for strengthening the noble character education of MAN students through scout extracurricular activities was carried out well. Second, the character education program implementation for MAN students through scout extracurricular activities has not achieved good service quality because of the assessment system. Third, the impact of strengthening the noble character of the MAN student character education program through Scout extracurricular activities has achieved its objectives; However, it can only be monitored when students are in school. Therefore, Madrasah Ibtidaiyah needs to develop SOPs to form noble character by supporting extracurricular activities.

\section{INTRODUCTION}

Character Education (PPK) is an educational policy aiming to implement Nawacita of President Joko Widodo-Jusuf Kalla in the national education system. This PPK policy is integrated into the National Movement of Mental Revolution (GNRM), namely the change into better mindset, behavior, and action. In addition, the essential values of PPK are religion, nationalism, independence, mutual cooperation, and integrity embedded and practiced through the national education system (Listiawati, 2018; Surachman, 2020). Thus, it will be acknowledged, understood, and implemented in schools or society (Bates, 2019; Kosim et al., 2019; Muhamad Nova, 2017). The Presidential Regulations about PPK outlines the objectives, 
as follows: equipping students with noble character education and spirit of Pancasila to be the golden generation in 2045, developing a national education platform upholding character education as the main spirit in administering education for students (Satria \& Shahbana, 2020). Furthermore, it is conducted through formal, non-formal, and informal education by concerning the diversity of Indonesian culture, and revitalizing and strengthening potentials and competencies of teachers, education personnel, students, societies, and families in implementing PPK. In addition, understanding background, urgency, and PPK basic concept is highly crucial for school principals so they can implement it based on the educational context in their schools (Huri \& Marwanto, 2019; Zaenab et al., 2020). As a matter of fact, character education is a new program prioritized by the Ministry of Education and Culture of Indonesia. Notwithstanding, the implementation of character education encounters multiple dilemmas, for example prioritizing examination or students' character education (Fatimah, 2019; Sulistyarini et al., 2019). A visible example of the dilemma in implementing character education is National Examination (Nur Aisyah et al., 2018). In the educational process, students are taught noble character; however, in the National Examination implementation, students are taught dishonesty which is extremely contrasting with the nation's character (Haniah et al., 2020; Zurqoni et al., 2018). Furthermore, character education as the educational reformation will be accomplished with the proper cooperation from the government as the policy maker, schools as the education administration unit integrating character education in the curriculum, and also teachers as the role model, parents as the first teacher of children's character, as well as society reflecting the culture and characters of the nation in daily life (Buchori Muslim, 2020; Pike et al., 2021; Yunanto et al., 2019). The success of character education will be visible if all components practice their respective function as best as they can (Sari, 2019; Solfema et al., 2019).

Unfortunately, character education implementation has several issues. For example, the incompatibility of the character education concept aiming to improve the culture and nation character which becomes worse day by day (Estuwardani \& Mustadi, 2016; Mawarni \& Suntoro, 2020; Rachmawati et al., 2018). Noble characters are strongly embedded in the school. Nevertheless, it is not supported by the community outside the school which does not reflect the noble characters learned at school (Hulukati \& Rahmi, 2020; Widiyasanti et al., 2018). Based on the preliminary study, it was identified that some teachers did not practice character education in their teaching because they only focused on the school management. The lack of concern on the school management consequently impacted on the students' character education in Islamic Senior High School. Additionally, character education integration and evaluation system of character education in Islamic Senior High School as an instrument to evaluate character development was not optimal. Moreover, all components or stakeholders must be engaged in the character education in school, including educational components, namely curriculum, learning and assessment process, subject management, school management, school activity administration or extracurricular activities, facilities utilization, funding, and working ethic for all education personnel and society (Hulawa, 2019; Warti'ah, 2020). Besides, character education is defined as a person with noble character in administering education. In order to support character education, extracurricular activities by the educational institution should be implemented. Extracurricular activities are intended to deepen and sharpen lessons learned in intracurricular activities (Feldman \& Matjasko, 2005; Saputro \& Murdiono, 2020; White et al., 2018). Moreover, extracurricular activities are meant to be a medium to elevate students' potential (Forneris et al., 2015; Matjasko et al., 2019; Morris, 2016). Hence, it can bring positive impacts in strengthening character education. Furthermore, extracurricular activities considerably support intra-curricular activities to promote students' understanding of the lesson they learn. Usually, the activities are assignment or homework, or other tasks related to the intra-curricular subjects which should be finished by the students.

Meanwhile, extracurricular activities are conducted to deepen and broaden students' knowledge related to the subject they choose (Mahoney, 2014; Metsäpelto \& Pulkkinen, 2012). As a matter of fact, extracurricular activities are part of education. Hence, extracurricular activities are processes done consciously and systematically to prepare students to face their future (Forneris et al., 2015; Noer et al., 2017). By having extracurricular activities, students are expected to be capable in various fields based on the competencies they have (Bakhri, 2018; Matjasko et al., 2019). In addition, students are expected to increase their faith in God, to be pious, to have knowledge and skill, to develop physical and mental health, to be noble and independent, as well as to be responsible in society and nation (Luthviyani et al., 2019; Metsäpelto \& Pulkkinen, 2012). In order to achieve the best result and shape the students' character, extracurricular activities should be supported with concrete effort, started from the government of central, provincial, regency/city, and school principal (Morris, 2016). It is stated in the National Education System Constitution, Article 4 paragraph 4, namely, education is administered by providing exemplary models, building strong willingness, and developing students' creativity in the learning process. As a result, educational institutions can prepare individuals who are strong in moral values, spiritual values, and knowledge (White et al., 2018; Yanzi, 2019). The findings of previous studies also stated that character 
education is critical given to students (Bates, 2019; Kosim et al., 2019; Ramdhani et al., 2019). Other research findings also state that character education is critical because it will form superior student attitudes unggul (Hulawa, 2019; Pike et al., 2021; Yunanto et al., 2019). Other research findings also state that character education is critical to developing a child's essential potential to be kind, behave well, and develop well (Nuryanti, 2019; Pradana et al., 2021; Thoyyibah et al., 2019). It can be said that character education is critical to note. This research intended to examine the implementation of the strengthening noble character education program of Islamic Senior High Schools through the Scouts.

\section{METHODS}

This research employed a qualitative research method with a case study in Islamic Senior High School 1 Pulang Pisau and Islamic Senior High School Palangkaraya. This research aimed to obtain information on the implementation of the strengthening noble character education program of Scouts activities in Islamic Senior High Schools. Owe to that matter, one of the most important methods in the case study was collaborative discussion related to the issue examined by researchers, namely the strengthening noble character education program of MAN students, the implementation of strengthening noble character education program of MAN students, and the impacts of strengthening noble character education program of MAN students. Therefore, the researchers could identify the information required to understand the case and decide on a problem to be investigated. Below are stages conducted in this research. This research was conducted in Islamic Senior High School 1 Pulang Pisau and Islamic Senior High School Palang Raya City, Central Kalimantan. The researchers selected these schools because they are the only schools in Palangkaraya and Pulang Pisang where Scouts activities are the most favored extracurricular activity. The research subjects were students. Meanwhile, the informant in this research was determined by purposive sampling. The informant selection was conducted on purpose based on several criteria. The key informant in this research was as follows: The principal of Curriculum and Students Affairs, Islamic Education Board, Ministry of Religion Affairs, Central Kalimantan, The principal of Islamic Senior High School 1 Pulang Pisau and Islamic Senior High School Palangkaraya, Vice Principal of Students Affairs of Islamic Senior High School 1 Pulang Pisau and Islamic Senior High School Palangkaraya, Students Council Advisor of Islamic Senior High School 1 Pulang Pisau and Islamic Senior High School Palangkaraya, and Board of Teachers of Islamic Senior High School 1 Pulang Pisau and Islamic Senior High School Palangkaraya.

Qualitative research as human instrument functions to decide a research focus, to select informant as a data source, to assess data quality and data analysis, to interpret data, and to draw a conclusion based on the findings. The procedures carried in this research were as follows: First, observation. The observation method in this research was employed as supporting methods, with teachers and students as the target. Especially, the researchers observed the implementation and application of Scouts activities as well as how the integration of strengthening noble character education was practiced. Second, Interview. A deep interview was conducted to obtain information on the topics decided (based on the objectives and intention of the interview) by providing questions related to the strengthening noble character education program of MAN students, the implementation of the strengthening noble character education program of MAN students, and the impacts of strengthening noble character education program of MAN students. In addition, the data employed was related to the documentation techniques. Third, Documentation. Documentation was carried out by collecting data from a written source to obtain information on profile MAN Pulang Pisau and MAN Palangkaraya, guidance on extracurricular program implementation, either written data or images, pictures, notes, books, newspaper, and other things related to the studied problem.

The data collection procedures of the qualitative research were conducted by designing research stages. There are three main stages in qualitative research, as follows: first, description or orientation stage. In this research, the researchers described what they have seen and heard related to the strengthening noble character education program of MAN students, the implementation of the strengthening noble character education program of MAN students, and the impacts of the strengthening noble character education program of MAN students. Second, reduction stage. In this research, the researchers reduced all information obtained in the first stage to focus on certain problems, namely character education on the Scouts activities in Islamic Senior High School. Third, Selection stage. In this stage, the researchers elucidated focus set out into more detail, and then analyzed the problems deeply. It results in themes constructed by the data obtained into knowledge, hypothesis, and even new theories (Sugiyono, 2018). In qualitative research, data analysis technique was conducted based on the data analysis model of Miles and Huberman (1984) (Miles et al., 2014). Theoretically, stages of data analysis refer to Moleong's opinion stating that to verify the data obtained and decided (Moleong, 2018). Data checking technique might be used based on the following criteria: First, Using credibility degree criteria to obtain data. Hence, data gained to analyze the strengthening noble character education program of MAN students, the 
implementation of strengthening noble character education program of MAN students, and the impacts of strengthening noble character education program of MAN students, are credible during the research. Second, Using transferability engagement criteria. Data shifting is carried out based on the situation and condition of the social condition of the environment existing (raw data). Third, Using dependency criteria. Data validity obtained is controlled by finding the evidence in doing the social actions or by observing or reinterviewing. Indeed, it is difficult to do since there is no event that will be repeated exactly the same. Nevertheless, this step is still carried out to be a good consideration. Fourth, Using confirmability criteria to obtain data as objective as possible. Then, the data obtained will be consulted with the key informant. The instruments are presented in Table 1.

Table 1. Research Question

\begin{tabular}{|c|c|c|c|c|c|}
\hline \multirow[t]{2}{*}{$\begin{array}{c}\text { Research } \\
\text { Objectives }\end{array}$} & \multirow[t]{2}{*}{ Research Indicators } & \multirow[t]{2}{*}{ Data Sources } & \multicolumn{3}{|c|}{$\begin{array}{c}\text { Research } \\
\text { Technique } \\
\text { s of Data } \\
\text { Source } \\
\end{array}$} \\
\hline & & & I & $\mathbf{0}$ & D \\
\hline $\begin{array}{l}\text { Strengthening } \\
\text { noble character } \\
\text { education } \\
\text { program of } \\
\text { MAN students }\end{array}$ & $\begin{array}{l}\text { - What is the aim of } \\
\text { strengthening noble } \\
\text { character education } \\
\text { program? } \\
\text { - What is the activities plan of } \\
\text { strengthening noble } \\
\text { character } \\
\text { program? } \\
\text { - What is the success standard } \\
\text { students' noble character } \\
\text { education? } \\
\text { - With whom do you } \\
\text { collaborate in implementing } \\
\text { the strengthening noble } \\
\text { character } \\
\text { program? } \\
\text { - What is the plan to measure } \\
\text { the success of noble character } \\
\text { education? }\end{array}$ & $\begin{array}{l}\text { - Head of Madrasah Education } \\
\text { Division, Regional Office of the } \\
\text { Ministry of Religious Affairs, } \\
\text { Central Kalimantan Province } \\
\text { - Head of Curriculum and Student } \\
\text { Affairs of Madrasah Education, } \\
\text { Regional Office of the Ministry of } \\
\text { Religious Affairs, Central } \\
\text { Kalimantan Province. } \\
\text { - Principal of Madrasah Aliyah } \\
\text { Negeri } 1 \text { Pulang Pisau and Kota } \\
\text { Palangka Raya. } \\
\text { - Vice Principal of Student Affairs of } \\
\text { Madrasah Aliyah Negeri } 1 \text { Pulang } \\
\text { Pisau and Kota Palangka Raya. } \\
\text { - Students Council Advisors of } \\
\text { Madrasah Aliyah Negeri } 1 \text { of } \\
\text { Pulang Pisau and the Kota } \\
\text { Palangka Raya. } \\
\text { - The Teacher Council of MAN } 1 \\
\text { Pulang Pisau and MAN Kota } \\
\text { Palangka Raya }\end{array}$ & $\sqrt{ }$ & $\sqrt{ }$ & $\sqrt{ }$ \\
\hline $\begin{array}{l}\text { Implementation } \\
\text { of the } \\
\text { strengthening } \\
\text { noble character } \\
\text { education } \\
\text { program of } \\
\text { MAN students }\end{array}$ & $\begin{array}{l}\text { - How is the preparation for } \\
\text { the implementation of the } \\
\text { strengthening noble } \\
\text { character education program } \\
\text { of MAN students? } \\
\text { - How is the socialization of } \\
\text { the implementation of the } \\
\text { strengtheVning noble } \\
\text { character education program } \\
\text { of MAN students? } \\
\text { - How is the coordination of the } \\
\text { implementation of the } \\
\text { strengthening noble } \\
\text { character education program } \\
\text { of MAN students? } \\
\text { - How is the implementation of } \\
\text { the strengthening noble } \\
\text { character partnership } \\
\text { program of MAN students? }\end{array}$ & $\begin{array}{l}\text { - Head of Madrasah Education } \\
\text { Division, Regional Office of the } \\
\text { Ministry of Religious Affairs, } \\
\text { Central Kalimantan Province } \\
\text { - Head of Curriculum and Student } \\
\text { Affairs of Madrasah Education, } \\
\text { Regional Office of the Ministry of } \\
\text { Religious Affairs, Central } \\
\text { Kalimantan Province. } \\
\text { - Principal of Madrasah Aliyah } \\
\text { Negeri } 1 \text { Pulang Pisau and Kota } \\
\text { Palangka Raya. } \\
\text { - Vice Principal of Student Affairs of } \\
\text { Madrasah Aliyah Negeri } 1 \text { Pulang } \\
\text { Pisau and Kota Palangka Raya. } \\
\text { - Students Council Advisors of } \\
\text { Madrasah Aliyah Negeri } 1 \text { of } \\
\text { Pulang Pisau and the Kota } \\
\text { Palangka Raya. }\end{array}$ & $\sqrt{ }$ & & $\sqrt{ }$ \\
\hline
\end{tabular}




\begin{tabular}{|c|c|c|c|c|c|}
\hline \multirow[t]{2}{*}{$\begin{array}{c}\text { Research } \\
\text { Objectives }\end{array}$} & \multirow[t]{2}{*}{ Research Indicators } & \multirow[t]{2}{*}{ Data Sources } & \multicolumn{3}{|c|}{$\begin{array}{c}\text { Research } \\
\text { Technique } \\
\text { s of Data } \\
\text { Source }\end{array}$} \\
\hline & & & I & $\mathbf{0}$ & D \\
\hline & $\begin{array}{l}\text { - What are the problems of the } \\
\text { implementation noble } \\
\text { strengthening nater } \\
\text { character education program } \\
\text { of MAN students? } \\
\text { - How is the implementation of } \\
\text { the noble character } \\
\text { assessment of MAN students? } \\
\text { - How are the efforts to } \\
\text { overcome the } \\
\text { implementation problems of } \\
\text { the strengthening noble } \\
\text { character program of MAN } \\
\text { students? }\end{array}$ & $\begin{array}{l}\text { - The Teacher Council of MAN } 1 \\
\text { Pulang Pisau and MAN Kota } \\
\text { Palangka Raya }\end{array}$ & & & \\
\hline $\begin{array}{l}\text { The impacts of } \\
\text { the } \\
\text { implementation } \\
\text { of } \\
\text { strengthening } \\
\text { noble character } \\
\text { education } \\
\text { program of } \\
\text { MAN students }\end{array}$ & $\begin{array}{l}\text { - What is the current actual } \\
\text { condition of the noble } \\
\text { character of MAN students? } \\
\text { - How is the current quality of } \\
\text { moral character education } \\
\text { services of MAN students? } \\
\text { - How are the facilities and } \\
\text { infrastructure prepared by } \\
\text { Madrasah in implementing } \\
\text { the strengthening noble } \\
\text { character education program } \\
\text { of MAN students? }\end{array}$ & $\begin{array}{l}\text { - Head of Madrasah Education } \\
\text { Division, Regional Office of the } \\
\text { Ministry of Religious Affairs, } \\
\text { Central Kalimantan Province } \\
\text { - Head of Curriculum and Student } \\
\text { Affairs of Madrasah Education, } \\
\text { Interview } \\
\text { 1. observation } \\
\text { - documentation Regional Office of } \\
\text { the Ministry of Religious Affairs, } \\
\text { Central Kalimantan Province. } \\
\text { - Principal of Madrasah Aliyah } \\
\text { Negeri } 1 \text { Pulang Pisau and Kota } \\
\text { Palangka Raya. } \\
\text { - Vice Principal of Student Affairs of } \\
\text { Madrasah Aliyah Negeri } 1 \text { Pulang } \\
\text { Pisau and Kota Palangka Raya. } \\
\text { - Students Council Advisors of } \\
\text { Madrasah Aliyah Negeri } 1 \text { of } \\
\text { Pulang Pisau and the Kota } \\
\text { Palangka Raya. } \\
\text { - The Teacher Council of MAN } 1 \\
\text { Pulang Pisau and MAN Kota } \\
\text { Palangka Raya }\end{array}$ & $\sqrt{ }$ & & \\
\hline
\end{tabular}

Notes : I=Interview; 0 = Observation; $\mathrm{D}=$ Documentation

\section{RESULT AND DISCUSSION}

\section{Results}

Based on the results of the interview and document tracking, it was obtained that the strengthening noble character education program of MAN Pulang Pisau students through the Scouts activities is designed by the Students Council Advisors together with the Vice Principals of Students Affairs. It is arranged at the beginning of the academic year. In addition, based on the observation and documents study conducted, the researchers obtained some information that this program aims to generate and equip the Golden Generation of Indonesia in 2045 to be ready to face the future with the 21 century skills. The objective of this program is to return character education as the educational spirit and foundation through ethics and spiritual harmony, aesthetic, literacy, and numeration, as well as kinesthetic. Additionally, it also tries to build students' character which is responsible, reliable, honest, polite, and grateful. Moreover, the interview results identified several activities arranged to strengthen the character education of MAN 1 Pulang Pisau 
students. These activities, among others, are strengthening religious programs, promoting nationalism, and strengthening cultural values, promoting integrity. Additionally, it includes independent activities and mutual cooperation activities. The interview results indicated plans of strengthening the noble character education of MAN 1 Pulang Pisau students. Some of the activities are habituation of shalat fardhu, reading Al Qur'an, greeting other people, and loving peace. In addition, students are taught tolerance, respecting differences, anti-bullying and violence, as well as mutual cooperation in school. Students should demonstrate nationalism by obeying rules and regulations in the school, attending flag ceremonies on Monday and other National Days, being independent, not depending on other people, improving working ethically, and being creative. The interview results related to the success standard of this program revealed that the quality of noble character values is gradually seen, developed, and embedded in the form of knowledge, attitude, and behavior of the students. The positive impacts of character education are demonstrated with the increase of students' parents to send their children to MAN 1 Pulang Pisau because they regard this school as capable of obeying and practicing Islamic teachings.

From the interview results, it was obtained that parents or other parties deemed competent were asked to have a meeting to coordinate the implementation character education program. It is expected to strengthen the implementation and commitment. Meanwhile, information gained from another respondent mentioned that the environment around the school also contributes to the success of the program. The school staffs and stakeholders participate actively to succeed in the character education program. Thus, the school's program runs well based on the resources, funds, and facilities. Plan to Measure the Success of Noble Character Education Program of MAN 1 Pulang Pisau Students Based on the interview and observation result, the success of this program was indicated as follows: 1 ) instructing all teachers to design a lesson plan with character education integrated into it; 2) instructing all teachers to teach character education; 3) evaluating alumni's profession after graduation; 4) concerning public's interest to send their children to this MAN 1 Pulang Pisau; and 5) observing students' attitude and behavior in daily life, including mindset, manner, words observed by all school personnel.

Based on the interview conducted to discover information about this program, it was found out that characters of religion, nationalism, culture, independence, mutual cooperation, and integrity were optimized. These characters are emphasized deeper to identify the students' actualization and to improve and parents' involvement to guide students. Additionally, the preparation to implement this program is also practiced by all school personnel and stakeholders. Furthermore, competent parents and other parties are invited to have a meeting to strengthen the implementation and commitment. It is continuously applied to accomplish the noble character education program. The socialization of this program is administered to educate students about the culture they have and follow. It aims to generate well-mannered students to live in their society and certain groups. In fact, socialization can be regarded as equal to education. For instance, an individual here is a student who needs a teacher's guidance to prepare themselves to live in their social life, namely the school environment. Furthermore, socialization aims to make students better than before. It is in line with the education goal to make students better than before. Socialization of noble character education values has been repeatedly taught by teachers. It is expected that students will understand and implement the values in their daily life.

The interview results with some informants revealed that the coordination of this program was carried out by inviting competent parents and other parties to a meeting. It is conducted to strengthen the implementation and commitment. Meanwhile, information gained from another respondent mentioned that the environment around the school also contributes to the success of the program. The school staffs and stakeholders participate actively to succeed the character education. Thus, the school's program runs well based on the resources, funds, and facilities. The coordination is conducted with the stakeholders and school advisors, such as the committee, supervisor, the Department of Islamic School of Ministry of Religion Affairs, and religion/public leaders. However, the implementation of character education requires cooperation from multiple parties and example from the teachers, education personnel, and parents. The coordination between schools and parents, for instance, is conducted when parents take students' report cards. If the cooperation between school and parents is great, the result will be much better. The interview results indicated that the implementation of this program partnership is administered with the Ministry of Religion Affairs of the Regency and Province, and the Board of education. As a matter of fact, this partnership program aims to strengthen cooperation between Islamic schools, families, and society. Thus, it can encourage making an effective learning environment to develop students' potential. This Islamic School partnership is also aimed to improve parents' involvement to support character education and students' success at home or school. The partnership program has been tied with several Scouts units, such as polices resort, the District Military Command of Pulang Pisau, and the Public Health Office. In addition, MAN 1 Pulang Pisau usually works together with the Indonesian Red Cross for charity. This kind of activity will grow social care, sensibility, and compassion. It is expected to influence students' characterd. 
There are several problems identified from the respondent in implementing this program. These problems are different students' educational backgrounds who are not graduated from Islamic schools. Consequently, growing religious attitudes became a challenge. The attitude of students, environment, and school sometimes are missed to assess and monitor. From the interview result with the Principal of MAN 1 Pulang Pisau, a number of problems were identified, among others: (1) Character values developed in the school has not been outlined in representative indicators. Consequently, it will lead to difficulty in measuring achievement, (2) School has not been able to choose character values aligned with their vision. There are numerous character values required by the Ministry of Education and Culture and other institutions. Commonly, Islamic Schools face a problem in selecting characters that are suitable for their vision. The more serious problem is the teachers' role to be a model in accomplishing character values, especially character values which are suitable with the character values in general and in the subject taught.

The assessment of noble character education of MAN 1 Pulang Pisau students is outlined in all subjects. Thus, the assessment does not rely only on the cognitive aspect. Another informant stated assessment result of character education is reported in the student's report card. For example, there is a score to reflect the personality aspect. The score must not be in numbers, but words: Good, Fair, and Poor. It will be better if it is described in sentences, such as "faith, honor, and nationalism are good, but this students' environment care is poor". Character is also assessed from the Scouts activities. Scouts activities are a guideline for developing the process of attitudes and skills. The educational activities in Scouts are accomplished in the form of environment and Scouts skills using various methods and techniques. The efforts done to overcome the implementation problems are by habituating in all students' activities and by giving examples on every occasion, especially in learning activities. Further, character education is not only decided by teachers but also parents and society.

The implementation of this character education in MAN 1 Pulang Pisau is relatively good. It is identified by the quality of noble character values which are gradually noticeable, developed, and embedded in various knowledge, attitude, and behavior of students. It is generally good, seeing from the characters shown in daily life, either inside or outside the school, because students often join religious activities. The implementation of character education covers all educational components, starting from the government as the policy maker of the national education system, managerial of the Principal of the Islamic Schools, teachers' competencies, facilities, curriculum, and support from the society. Nevertheless, the most influential factor is teachers. Teachers should work hard to guide students to be pious and honorable. Thus, it is expected that teachers with their personality competencies can implement character education in MAN 1 Pulang Pisau. Based on the interview and observation results conducted, it was revealed that the principal's creativity contributes massively to managing character education in the school. Thus, the character education in this school is categorized as successful. The principal is capable of creating conducive situation in the school, embedding Islamic culture through IMTAQ education, and implementing rules of being discipline in time, work, and commitment. According to the Student Council Advisors of MAN 1 Pulang Pisau, Islamic Schools with high quality are reflected from the facilities they have. Islamic School is said to have high quality if there are complete facilities supporting the learning process. Based on the observation carried out in the research location, the facilities that MAN 1 Pulang Pisau offers relatively support the implementation of the noble character education. This school has classrooms, a library, sports facilities, musholla, and rooms for religious activities.

Based on the interview conducted with participants, it is discovered that the Vice Principal of Students Affairs aims to embed and equip the young generation with noble character, high literacy skill, and excellent skill of 21 century, namely being critical and analytical, creative, communicative, and collaborative. The results of interviews with participants, observation, and documentation study conducted in MAN Palangkaraya identified that this character education aims to develop students' understanding of moral values. Hence, it is expected that students are capable of thinking, feeling, and acting in honorable behavior. Meanwhile, another source stated that the purpose of this character education is to generate students with noble and honorable character, either from saying, acting, or socializing with students, teachers, parents, society, and nation. In addition, this character education program is also implemented in certain activities for students living in a dormitory. The activities are regular recitation. The activities of character education are intensively conducted in a dormitory. These activities greatly influence the students' character education. The activities implemented so far are tahfidz, muhadharah, khateeb and bilal, mauled al habsyi activities, calligraphy activities. Meanwhile, for students, religious activities related to noble character education is Dhuha prayer in the congregation. Dhuha prayer must be conducted by all classes in turn and all classes altogether. In the middle of Dhuha prayer, there is a short speech where students read hadith guided and monitored by teachers. It is one of the noble character education implementations in MAN Palangkaraya which is in line with the planning arranged by the school. 
Based on the results of the interview about the success standards of students' noble character education, it revealed that students gradually show noble characters. It is started to develop and embed in the form of knowledge, attitudes, and behavior of students. Tangible success indicators in character education include honesty, responsibility, obedience and discipline to applicable regulations, religious obedience, politeness, friendliness, diligence in prayer, caring for others, and disliking of brawls, academic and non-academic achievements in various competitions that are participated. Another indicator is the implementation of an academic curriculum that supports student progress and other school personnel to be responsible for and have an open and democratic Islamic School leadership. Meanwhile, other informants stated that the success standards of character education for MAN Palangkaraya students include success indicators of managing noble character education, which is shown by the quality of the values of noble character education that are gradually visible. It starts to develop and become embedded in the form of knowledge, attitudes, and the behavior of students. Noticeable success indicators in character education are honesty and responsibility. In addition, the success standards of noble character education of MAN Palangkaraya City students are achieving Islamic School culture, namely behavior, traditions, daily habits, and symbols that are practiced by all school personnel and the surrounding community based on the values of noble characters.

In implementing the character education program, the school collaborates with the Islamic school committee. Based on the results of interviews with participants, it was stated that the Principal of Islamic School is not only an education manager but also as an advisor, supporter, controlling agency, and mediator between the government (executive) with the society and with the Islamic School in the implementation of character education. Furthermore, other participants described that the Scouts activities are done by collaborating with institutions that have Scouts activities, including Public Health Office, Palangkaraya Police, and Forestry Service. The Scouts advisors in school will hold training to strengthen character education. Each of the extracurricular activities aims to instill character strengthening. The most highlighted character values are religious character, nationalism, independence, mutual cooperation, integrity, and unity. Based on the results of interviews from participants, the plan to measure the success of noble character education is as follows: establishing indicators of character education assessment, having instruments of character education assessment, conducting analysis and evaluation, and supervising the success of implementing character education and carrying out follow-up actions. In addition, indicators of success will be made in the report card assessment. Scouts activities are mandatory extracurricular activities, thus, it will be written on the report card. The score ranges from A: excellent, B: good, and C: fair. On the other hand, other interview participants stated that the success of the strengthening noble character education program can be seen when there is a violation. If a student violates, it refers that she/he does not obey school regulations.

Based on the results of interviews and document studies conducted at MAN Palangkaraya City about this program, it is discovered that this school has academic and non-academic extra-curricular activities. One of the academic activities is Scout activities. Thus, schools must provide and facilitate adequate services and infrastructure for Scouts activities so it can run well. Meanwhile, other participants confirmed that the preparation stage starts from an arrangement of plan, activity stages, and schedule. Moreover, this stage includes collecting data and checking students' attendance, contacting informant, preparing facilities/media, contacting stakeholders, and preparing budget if needed. Annually, the student council advisor makes work plans for each activity, starting from training, equipment required, costs for competition, and others. The proposals made by each of the student council advisors are then coordinated by the Vice Principal of Students Affairs to be included in student programs in one academic year.

Based on the interview with the participants, it is stated that to socialize character education, Scout activities are included in the curriculum. In a ceremony of the Scouts, the advisors will deliver a speech and messages, so students will be used to be disciplined. Moreover, students will take the turn to be ceremony officers. The research participants described that coordination is carried out with stakeholders and school supervisors, such as Islamic school committees, supervisors, the Board of Islamic School Education of the Ministry of Religion Affairs, and religious/community leaders. Meanwhile, coordination in Scouts activities is started from the Scouts coordinator together with the Scouts administrators to compile the budgets needed for the activity. Then the Scouts coordinator submits activity proposals and budget planning to Vice Principals of Students Affairs. The partnership program for this program runs well and harmoniously, especially with religious leaders/religious organizations such as NU and Muhammadiyah, and others. The partnership runs smoothly due to the same vision and mission in implementing character education to students/society. In addition, MAN Palangkaraya actively participates in the regional and provincial competition. As a result, MAN Palangkaraya City dominates the championship.

The interview results from the research subjects indicated that there are problems faced in implementing the character education programs. An example of the problem is students do not understand 
the goals and noble character education. In addition, the students' social background and economic status considerably influence the students' mindset and behavior. Besides, not all teachers can integrate character education into the subjects taught. Additionally, the budget issue is also a major problem in implementing this program due to the gap between the fiscal year and the school year. As a matter of fact, extracurricular activities are carried out from mid-year in August, while the fiscal year is started in January. Such conditions can cancel some activities in the plan. In assessing this program, an interview with the Principal of the MAN Palangkaraya was conducted. It is discovered that the teacher profession is no longer regarded as a respectable profession. In fact, several dispute cases between teachers and parents indicate that teachers are no longer respected. Most of the disputes occur because parents cannot accept the way the teachers warn or punish students. Regarding the assessment of the noble character of MAN Palangkaraya students, it is stated that students actively joining Scouts activities are used to be a leader, for example in the school organizations. Usually, the committee of Students Council and Flag Hoisting Troop are dominated by Scouts students. There are even some students who become excellent students in a university, police, and soldiers.

In order to overcome the problem of implementing this character education program, the role of teachers should be maximized so they can understand and know their students better, especially homeroom teachers. This homeroom teacher must be able to go directly to find out the potential and interests of students' talents, especially in terms of learning. Second, homeroom teachers should be capable of motivating students to join extracurricular activities. Other ways to overcome these problems based on other informants are as follows: socialization of character education program to students, parents, and teachers through the learning process in class and outside the classroom such as extracurricular activities, banners, and magazines. Besides, they need to habituate noble characters to students in the school and surrounding environment as well as at home. Additionally, teachers' religious understanding should be improved so that they can integrate the values of character and noble morals in the learning process.

The noticeable present characters of MAN Palangkaraya are loving God and environment, responsibility, discipline, independence and honesty, respect and politeness, compassion, caring and team working, confidence, creativity, hard work, and persistence, justice, and leadership, and many others. It refers that students have noble characters. Students will do their tasks without asking because they are disciplined. Students who used to talk harshly and impolitely become polite. They act well when they become leaders or followers. They also show good progress toward parents and teachers after joining Scouts. In addition, this character education program in MAN Palangkaraya brings a good impact on achievement. However, the characters might be still low, especially in terms of speech. Some students are not well mannered in speaking. Based on the document study, the Scouts Advisors of MAN Palangkaraya coordinated with the Scouts of Public Health Officer, Forestry, Police, and National Armed Forces of Indonesia. Character education presently is regarded as a smart solution in overcoming issues faced by the nation. Consequently, character education and cultural education are necessary to be integrated into the policies for the implementation of basic, secondary, and tertiary education. Facilities prepared by MAN Palangkaraya to support the implementation of the character education program are relatively complete. Moreover, it is supported with an adequate fund. Facilities prepared for character education are classroom, library, laboratory, religious activities room, art room, sports facility, and so on. Gudep Antasari MAN Palangkaraya has also a separate secretariat room with adequate facilities.

\section{Discussion}

This program aims to shape the students' moral under the principles of islamic teachings. Certainly, this noble character teaching is not an easy task for teachers (Bates, 2019; Kosim et al., 2019; Muhamad Nova, 2017). It requires cooperation, understanding, and commitment of the madrasah community and the society. Scouts extracurricular activities are regarded being able to educate students to be disciplined, responsible, to have leadership attitude, to build cooperation and help each other (Pike et al., 2021; Yunanto et al., 2019). Character education is a conscious and planned effort to create an atmosphere and process of empowering the potential and cultivating students for unique personal or group characters as citizens (Hulawa, 2019; Pradana et al., 2021; Putrayasa, 2017). There are many values of noble character education that can be obtained through student development. Hence, that the purpose of student development is relevant. The implementation of the strengthening noble character education program is carried out in extracurricular activities (Luthviyani et al., 2019; Putri, 2017). These activities are carried out inside and/or outside the madrasah environment in order to expand knowledge, improve skills, and internalize religious, local national, and global values (Basuki \& Febriansyah, 2020; Khamalah, 2017; Yanto, 2020). It is expected that students be kindhearted human. Therefore, these activities are to help students' development based on their needs, potentials, talents, and interests (Erliani, 2017; Sujatmiko et al., 2019). These activities are conducted by capable and skilled teachers and/or educational staff. The impacts of this program are the generation of students who are strong, competitive, pious, tolerant, cooperative, patriotic, dynamic, and 
knowledgeable, which are imbued with faith and piety to god almighty based on pancasila. In addition, students also have the potential to become human beings who believe and fear god almighty, have noble character, are healthy, knowledgeable, capable, creative, independent, and become democratic and responsible citizens. The findings of previous studies also stated that extracurricular activities can improve students' character (Elisa et al., 2019; Luthviyani et al., 2019; Putri, 2017). It can be concluded that positive extracurricular activities can improve students' character.

\section{CONCLUSION}

From this research, it can be concluded that the implementation of strengthening the noble character education program of Islamic Senior High School through extracurricular activities has been conducted properly. In order to support that program, Islamic Senior High School should elevate noble character education for students by utilizing the whole school elements. Hence, Islamic Senior High School should arrange an SOP to shape noble character by supporting extracurricular activities. One of the extracurricular activities which can shape the noble character of students is the Scouts which strongly affects the students' behavior and achievement.

\section{REFERENCES}

Bakhri, S. (2018). Hubungan Kegiatan Ekstrakurikuler Pramuka dengan Tingkat Religiusitas Siswa SMA Negeri 1 Tangen (Perspektif Teori Sistem Sosial Talcott Parsons). Jurnal Sosiologi Agama, 12(1). https://doi.org/10.14421/jsa.2018.121-04.

Basuki, D. D., \& Febriansyah, H. (2020). Pembentukan Karakter Islami melalui Pengembangan Mata Pelajaran Akidah Akhlak di Madrasah Aliyah An-Najah Bekasi. Jurnal Intelektual: Jurnal Pendidikan Dan Studi Keislaman, 10(2). https://doi.org/10.33367/ji.v10i2.1209.

Bates, A. (2019). Character education and the 'priority of recognition.' Cambridge Journal of Education, 49(6), 695-710. https://doi.org/10.1080/0305764X.2019.1590529.

Buchori Muslim, A. (2020). Character Education Curriculum in the Government of Indonesia Strengthening Character Education Program. JIEBAR : Journal of Islamic Education: Basic and Applied Research, 1(2), 137-153. https://doi.org/10.33853/jiebar.v1i1.101.

Elisa, Prasetyo, \& Hadi. (2019). Penanaman Nilai-Nilai Pendidikan Karakter Siswa melalui Kegiatan Ekstrakurikuler Pramuka. Mimbar PGSD Undiksha, 7(2), 114-121. https: //doi.org/10.23887/jjpgsd.v7i2.17553.

Erliani, S. (2017). Peran Gerakan Pramuka Untuk Membentuk Karakter Kepedulian Sosial dan Kemandirian (Studi Kasus di SDIT Ukhwah dan MIS An-Nuriyyah 2 Banjarmasin). Jurnal Ilmiah Pendidikan Guru Madrasah Ibtidaiyah, VII(1). https://doi.org/10.18592/aladzkapgmi.v7i1.2020.

Estuwardani, N. A., \& Mustadi, A. (2016). Pengembangan Bahan Ajar Modul Tematik-Integratif Dalam Peningkatan Karakter Peserta Didik Kelas I Sekolah Dasar. Jurnal Pendidikan Karakter, o(2), 157172. https://doi.org/10.21831/jpk.v0i2.8620.

Fatimah, A. A. and S. (2019). Implementation of Strengthening Values of Nationalism in Character Education Through History Learningin Public Senior High School 1 Sungai Penuh. International Journal of Educational Dynamics, 1(2), 116-124. https://doi.org/10.24036/ijeds.v1i2.138.

Feldman, A. F., \& Matjasko, J. L. (2005). The role of school-based extracurricular activities in adolescent development: A comprehensive review and future directions. Review of Educational Research, 75(2), 159-210. https://doi.org/10.3102/00346543075002159.

Forneris, T., Camiré, M., \& Williamson, R. (2015). Extracurricular Activity Participation and the Acquisition of Developmental Assets: Differences Between Involved and Noninvolved Canadian High School Students. Applied Developmental Science, 19(1), 47-55. https://doi.org/10.1080/10888691.2014.980580.

Haniah, A. R., Aman, A., \& Setiawan, R. (2020). Integration of strengthening of character education and higher order thinking skills in history learning. Journal of Education and Learning (EduLearn), 14(2), 183. https://doi.org/10.11591/edulearn.v14i2.15010.

Hulawa, D. E. (2019). Al-Zarnuji's Character Concept in Strengthening Character Education in Indonesia. Jurnal Pendidikan Islam, 4(2), 25-40. https: //doi.org/10.15575/jpi.v4i2.2395.

Hulukati, W., \& Rahmi, M. (2020). Instrumen Evaluasi Karakter Mahasiswa Program Pendidikan Guru Pendidikan Anak Usia Dini. Jurnal Obsesi: Jurnal Pendidikan Anak Usia Dini, 4(2). https://doi.org/10.31004/obsesi.v4i2.468.

Huri, A., \& Marwanto, M. (2019). Implementation of Model Strengthening Religious Character Education and Nationalists at Muhammadiyah Plus Elementary School City of Salatiga Academic Year 
2017/2018. MUDARRISA: Jurnal Kajian Pendidikan Islam, 11(2), 101-113. https://doi.org/10.18326/mdr.v11i2.101-113.

Khamalah, N. (2017). Penguatan Pendidikan Karakter di Madrasah. Kependidikan, 5(2), 200-215. https://doi.org/10.24090/jk.v5i2.2109.

Kosim, M., Kustati, M., Sabri, A., \& Mustaqim, M. (2019). Strengthening Students' Character through Tahfidz Quran in Islamic Education Curriculum. Jurnal Pendidikan Islam, 8(1). https://doi.org/10.14421/jpi.2019.81.69-94.

Listiawati, N. (2018). The implementation of the strengthening character education in sdn 09 mataram city, nusa tenggara barat. Jurnal Pendidikan Karakter, 8(1), 17-28. https://doi.org/10.21831/jpk.v8i1.21668.

Luthviyani, Setianingsih, \& Handayani. (2019). Analisis Pelaksanaan Ekstrakurikuler Pramuka Terhadap Nilai-nilai Karakter Siswa di SD Negeri Pamongan. Jurnal Ilmiah Pendidikan Guru Sekolah Dasar, 12(2), 113-122. https://doi.org/10.33369/pgsd.12.2.113-122.

Mahoney, J. L. (2014). School Extracurricular Activity Participation and Early School Dropout: A MixedMethod Study of the Role of Peer Social Networks. Journal of Educational and Developmental Psychology, 4(1), 143-154. https://doi.org/10.5539/jedp.v4n1p143.

Matjasko, J. L., Holland, K. M., Holt, M. K., Espelage, D. L., \& Koenig, B. W. (2019). All Things in Moderation? Threshold Effects in Adolescent Extracurricular Participation Intensity and Behavioral Problems. Journal of School Health, 89(2), 79-87. https://doi.org/10.1111/josh.12715.

Mawarni, H., \& Suntoro, I. (2020). Management of Strengthening Character Education at Pondok Pesantren Nurul Ikhlas Tulang Bawang. International Journal of Science and Research (IJSR), 9(11), 775-782. https://doi.org/10.21275/SR201113141025.

Metsäpelto, R. L., \& Pulkkinen, L. (2012). Socioemotional Behavior and School Achievement in Relation to Extracurricular Activity Participation in Middle Childhood. Scandinavian Journal of Educational Research, 56(2), 167-182. https://doi.org/10.1080/00313831.2011.581681.

Miles, Huberman, \& Saldana. (2014). Qualitative Data Analysis. In A Methods Sourcebooks, Edition 3. SAGE Publication, Inc.

Moleong, L. J. (2018). Metodologi Penelitian Kualitatif. Remaja Rosdakarya.

Morris, D. S. (2016). Extracurricular Activity Participation in High School: Mechanisms Linking Participation to Math Achievement and 4-Year College Attendance. American Educational Research Journal, 53(5), 1376-1410. https://doi.org/10.3102/0002831216667579.

Muhamad Nova. (2017). Character Education In Indonesia EFL Classroom Implementation and Obstacles. Jurnal Pendidikan Karakter, 7(2). https://doi.org/10.21831/jpk.v7i2.13650.

Noer, A., Tambak, S., \& Rahman, H. (2017). Upaya Ekstrakurikuler Kerohanian Islam (ROHIS) dalam Meningkatkan Sikap Keberagamaan Siswa di SMK Ibnu Taimiyah Pekanbaru. Jurnal Pendidikan Agama Islam Al-Thariqah, 2(1). https://doi.org/10.25299/althariqah.2017.vol2(1).645.

Nur Aisyah, E., Samawi, A., \& Fitri Untariana, A. (2018). Efforts to Improve the Ability of The Teachers in Development Program for Strengthening Character Education (PPK) in Early Childhood Education (ECE) through Workshop Activities. Proceedings of the 1st International Conference on Early Childhood and Primary Education (ECPE 2018), 244(Ecpe), 38-41. https://doi.org/10.2991/ecpe18.2018.9.

Nuryanti, A. D. (2019). Character Education and Creativity of Ideas in the Speech Acts of the Main Character of the Fantasy Text Based on Local Wisdom. St International Conference on Language, Literature, and Arts Education, 146. https://doi.org/10.2991/assehr.k.200804.047.

Pike, M. A., Hart, P., Paul, S. A. S., Lickona, T., \& Clarke, P. (2021). Character development through the curriculum: teaching and assessing the understanding and practice of virtue. Journal of Curriculum Studies, 53(4), 449-466. https://doi.org/10.1080/00220272.2020.1755996.

Pradana, D. A., Mahfud, M., Hermawan, C., \& Susanti, H. D. (2021). Nasionalism: Character Education Orientation in Learning Development. Budapest International Research and Critics Institute (BIRCIJournal): Humanities and Social Sciences, 3(4), 4026-4034. https://doi.org/10.33258/birci.v3i4.1501.

Putrayasa, I. B. (2017). Literature as Media Education Nation Character Values. International Journal of Linguistics, Literature, and Culture, 3(3), 1-9. https://doi.org/10.21744/ijllc.v3i3.443.

Putri, I. B. T. (2017). Penanaman Nilai-nilai Karakter melalui Ekstrakurikuler Pramuka di MAN 1 Yogyakarta. Jurnal Pendidikan Kewarganegaraan Dan Hukum, 431-441.

Rachmawati, W., Benty, D. D. N., \& Sumarsono, R. B. (2018). Budaya Sekolah Berbasis Ketarunaan Dalam Pembentukan Karakter Peserta Didik. Jurnal Administrasi Dan Manajemen Pendidikan, 1, 410-418. https://doi.org/10.17977/um027v1i42018p410. 
Ramdhani, S., Yuliastri, N. A., Sari, S. D., \& Hasriah, S. (2019). Penanaman Nilai-Nilai Karakter melalui Kegiatan Storytelling dengan Menggunakan Cerita Rakyat Sasak pada Anak Usia Dini. Jurnal Obsesi : Jurnal Pendidikan Anak Usia Dini, 3(1), 153. https://doi.org/10.31004/obsesi.v3i1.108.

Saputro, J. D., \& Murdiono, M. (2020). Implementation of Character Education through a Holistic Approach to Senior High School Students. International Journal of Multicultural and Multireligious Understanding, 7(11), 460-470. https://doi.org/10.18415/ijmmu.v7i11.2146.

Sari, C. S. (2019). Strategic Management of Increasing Competency of Students Though Strengthening Character Education (PPK) and School Literation Movement (GLS) at Muhammadiyah Junior High School Margasari. International Conference of Moslem Society, 3(2010), 48-57. https://doi.org/10.24090/icms.2019.2434.

Satria, R., \& Shahbana, E. B. (2020). The SWOT Analysis of Strengthening Character Education In Junior High School. Jurnal Iqra': Kajian Ilmu Pendidikan, 5(2), 56-67. https://doi.org/10.25217/ji.v5i2.827.

Solfema, Wahid, S., \& Pamungkas, A. H. (2019). The Development of Character through Extra-Curricular Programs. 1st International Conference on Education, Social Sciences and Humanities (ICESSHum), 335(ICESSHum), 918-926. https://doi.org/10.2991/icesshum-19.2019.143.

Sugiyono. (2018). Metode Penelitian Kuantitatif. Alfabeta.

Sujatmiko, I. N., Arifin, I., \& Sunandar, A. (2019). Penguatan Pendidikan Karakter di SD. Jurnal Pendidikan, 4(8), 200-215. https://doi.org/10.24090/jk.v5i2.2109.

Sulistyarini, S., Utami, T., \& Hasmika, H. (2019). Project Citizen Model as Character Education Strengthening.

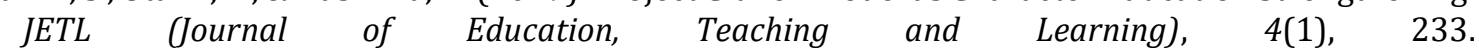
https://doi.org/10.26737/jetl.v4i1.1023.

Surachman, A. I. (2020). Penguatan pendidikan karakter berbasis komunitas masyarakat melalui perempuan fatayat $\mathrm{NU}$ di era globalisasi. Tarbawi: Jurnal Pendidikan Islam, 16(2). https://doi.org/10.34001/tarbawi.v16i2.1171.

Thoyyibah, N., Hartono, R., \& Bharati, D. A. L. (2019). The Implementation of Character Education in the English Teaching Learning Using 2013 Curriculum. English Education Journal, 9(2), 254-266. https://doi.org/10.15294/eej.v9i2.30058.

Warti'ah, W. (2020). The Implementation of Madrasa Culture in Building Students' Character. Nazhruna: Jurnal Pendidikan Islam, 3(2), 247-259. https://doi.org/10.31538/nzh.v3i2.583.

White, T., Scott, L. D., \& Munson, M. R. (2018). Extracurricular activity participation and educational outcomes among older youth transitioning from foster care. Children and Youth Services Review, 85, 1-8. https://doi.org/10.1016/j.childyouth.2017.11.010.

Widiyasanti, M., Proketen, S. D., \& Yogyakarta, N. (2018). Pengembangan Media Video Animasi Untuk Meningkatkan Motivasi Belajar Dan Karakter Tanggung Jawab Siswa Kelas V. Jurnal Pendidikan Karakter, 8(1), 1-16. https://doi.org/10.21831/jpk.v8i1.21489.

Yanto, M. (2020). Manajemen kepala Madrasah Ibtidaiyah dalam menumbuhkan pendidikan karakter religius pada era digital. Jurnal Konseling Dan Pendidikan, 8(3), 176-183. https://doi.org/10.29210/146300.

Yanzi, H. (2019). Analysis for Strengthening Community-Based Character Education. International Journal of Arts, Humanities and Management Studies, 05(01), 12. https://doi.org/10.33578/jtlee.v4i2.7896.

Yunanto, A. A., Herumurti, D., Rochimah, S., \& Kuswardayan, I. (2019). English Education Game using NonPlayer Character Based on Natural Language Processing. Procedia Computer Science, 1. https://doi.org/10.1016/j.procs.2019.11.158.

Zaenab, S., Chamisijatin, L., \& Wahyuni, S. (2020). Strengthening character education through literacy movement at Muhammadiyah junior high schol. Journal of Community Service and Empowerment, 1(1), 54-63. https://doi.org/10.22219/jcse.v1i1.11516.

Zurqoni, Retnawati, H., Arlinwibowo, J., \& Apino, E. (2018). Strategy and implementation of character education in senior high schools and vocational high schools. Journal of Social Studies Education Research, 9(3), 370-397. https://doi.org/10.17499/jsser.01008. 